\title{
Application of spatio-temporal scan statistics for the detec- tion of areas with increased risk for American visceral leishmaniasis in the state of Bahia, Brazil
}

\author{
Deborah D.M.T. Carneiro, ${ }^{1,2}$, Maria E. Bavia', Washington J.S.F. Rocha ${ }^{3}$, Antônio C.Q. \\ Tavares $^{4}$, Luciana L. Cardim ${ }^{1}$, Biruk Alemayehu ${ }^{5}$ \\ ${ }^{1}$ School of Veterinary Medicine, Federal University of Bahia, Salvador, Brazil; ${ }^{2}$ Secretariat of Health of Bahia \\ State, Salvador, Brazil; ${ }^{3}$ State University of Feira de Santana; ${ }^{4}$ Department of Polices Technique, Salvador, \\ Brazil; ${ }^{5}$ Nelson Mandela School of Public Policy and Urban Affairs Southern University Baton Rouge, USA
}

\begin{abstract}
Mirroring the global increase of registered cases of American visceral leishmaniasis (AVL), this infection has become a growing public health problem in Brazil during the last several years. As the traditional approach to control employed by the governmental health agencies has failed to reduce the incidence and epidemic outbreaks of this illness, we propose a re-evaluation of the national strategy of intervention and monitoring. Our thinking is based on a series of spatio-temporal scan statistics of the west-central region of the state of Bahia covering the 11-year period from 1994 to 2004. By analyzing the situation, spatially and temporally, we show that the disease is a not only a growing focal threat but that it is also appearing in the form of endemic clusters in the cities. The areas where the disease has been found have been classified according to the degree of risk of infection for humans and canines. The overall objective of this study was to identify areas of increased risk of AVL, including its seasonality, and to suggest ways and means to improve the detection of the disease. The findings presented here should not only be of interest for the efforts to control AVL in the study area but also be useful for developing control strategies in other endemic regions of Brazil.
\end{abstract}

Keywords: American visceral leishmaniasis, spatial analysis, cluster detection, control.

\section{Introduction}

Reflected by a significant increase of the number of cases of American visceral leishmaniasis (AVL) globally, the threat caused by the Leishmania parasite is gaining in significance and this group of diseases is now considered by the World Health Organization (WHO) as one of its priorities. AVL is endemic in many different regions of the world and it is estimated that about 200 million individuals are at risk (WHO, 2002; Gontijo and Melo, 2004). AVL

Corresponding author:

Deborah Daniela Madureira Trabuco Carneiro

Av. Adhemar de Barros, 500

Escola de Medicina Veterinária da UFBA

Departamento de Medicina Veterinária Preventiva, sala 119

Ondina, Salvador, Bahia, Brasil

Tel. +55 7132836745 Fax +55 7132836730

E-mail:ddmtc@msn.com and other Leishmania infections are now considered re-emerging diseases with a serious public health impact.

The increase of AVL is felt to be mainly due to environmental influences (Forattini, 1973). Apart from the more general impact of the El Niño (Franke et al., 2002b), it is obvious that human activities with regard to the environment have favoured the dispersion of reservoirs and vectors thereby modifying its clinical character in relation to the changing landscape and expanded its geographical distribution (Miranda et al., 1998; Kawa and Sabroza, 2002). Although the changing environment has a negative influence with regard to the spread of the leishmaniases, it has also permitted the development of new means to identify and define the risk which can be used to anticipate and control outbreaks in the future. 
In Brazil, the disease is widely distributed and is regarded as endemic in more than $70 \%$ of the territories, particularly in the northeast. An average of 3700 new cases of leishmaniasis is registered each year (Brasil, 2004) and with 914 cases/year on average and 217 endemic municipalities (SESAB, 2005), the state of Bahia has both the highest rates of the disease and the largest number of new cases. Initially, the problem was concentrated in the center of the state but in the last few years the disease has expanded to the west, north, northeast and also towards the coastal areas (Franke et al., 2002a; Oliveira and Araújo, 2003). The municipalities of the center-east region have been a constant concern for the control programme for endemic diseases but the increasing economic importance of the area and the growing road system have attracted intense migration leading to a strong increase of prevalence and incidence of these diseases (SEI, 1997; Oliveira and Araújo, 2003).

By evaluating the environmental impact on AVL through directing data searches towards aggregation of events in particular places, the quality of the information obtained may be enriched in comparison to what can be obtained by purely spatial analysis. The distribution can be studied in an individual approach, in which case the event is represented by a point, or it can be done by using groups as the units representing the areas under investigation (neighbourhood, city, sector, etc.) (Câmara et al., 2002; Tavares, 2006). In the study of the geographical distribution of a disease, it is either possible to carry out an exploratory analysis with the objective to describe and explain how the disease appears from a purely spatial viewpoint or, alternatively, to examine if there exists a spatial dependence of the standard distribution (Hills and Alexander, 1989; Marshall, 1991; Bailey and Gatrell, 1995; Lawson and Kulldorff, 1999; Morais-Neto et al., 2001). This type of precise information in relation to the casual characteristics of determined events makes it possible for health agencies to produce better and more selective policies for intervention and control (Costa et al., 2006). By applying this thinking to the AVL problem, one can identify its spatial distribution as well as find the delimitation of its risk areas. However, the analysis of absolute numbers to indicate such areas can lead to false results and the use of gross rates in heterogeneous risk areas can also lead to mistakes. Statistical treatment of data without an ecological spatio-temporal analysis suppresses information that can be crucial since simple spatial distribution of cases does not constitute the complete information necessary to consider the situation properly. It is important to not only provide the biological data and their coordinates properly, but also to show how this information is treated in the analysis (Beato-Filho et al., 2001). The geographical distribution of available gross rates makes it possible to easily visualize regions with apparently high concentrations of events such as, for example, cases of AVL in humans and canines. According to Beato-Filho et al. (2001), the ultimate issue is to know whether or not the apparent aggregation of a high incidence and/or prevalence is random or if an increased number of observed cases can be attributed to increased exposure to infection. Accurate statistics must be applied to verify which of these two possibilities find significant support to make it true.

New ways to test for the existence of areas of particularly high risk have been considered and published. One of the most promising at the present time is the so-called spatial scan statistics (Kulldorff and Nagarwalla, 1995), which can be used to investigate if the one-dimensional processes of point collection are randomly distributed or if agglomerations of cases can be identified (Kulldorff, 1997).

The objective of this work was to show, through georeferenced maps, the distribution of human and canine AVL and the detection of agglomerates in the center-east region of Bahia, Brazil. The findings should contribute to improved control measures for this disease in the state of Bahia as well as in other endemic areas of Brazil. 


\section{Materials and methods}

\section{Study area}

The center-east region of the state of Bahia, which is situated in the eastern part of Brazil, is composed of 26 municipalities which, health wise, abide by the policies of the $2^{\text {nd }}$ Regional Directories of Health $\left(2^{\text {nd }}\right.$ DIRES), an administrative division of the Secretariat of Health of Bahia (Fig. 1). The municipalities make up the economic region of the Paraguaçu (SEI, 2000) which has a territorial extension of $14,021 \mathrm{~km}^{2}$ and 941,139 inhabitants. The average population density is 67.1 inhabitants $/ \mathrm{km}^{2}$ (IBGE, 2000). The vegetation cover of the region is dominated by small, thorny trees (caatinga) interspaced with transitory areas of dry forest ecosystems including woodland and savanna (cerrado). The area is semi-arid, with typical seasonal subhumid to dry spells and has a registered minimum temperature of $23.4^{\circ} \mathrm{C}$ and a maximum of $31.1^{\circ} \mathrm{C}$. The rainfall varies from a minimum pluviometer rate of $9.6 \mathrm{~mm}$ and a maximum of $1035.5 \mathrm{~mm}$.

\section{Epidemiological data}

Information for the period 1994-2004 pertinent to autochthonous AVL comes from the Municipalities Health departments (SMS) and the Secretariat of Health of Bahia State (SESAB, 2005). It provides the number of human cases, municipalities of occurrence, year and gender with calculation of incidence (number of new cases of autochthon AVL in relation to total population) as well as information on canine infections by serology (number of positive animals, municipalities of occurrence and year) with calculation of the rate of seropositive canines (number of positive dogs in relation to the total number of examined dogs).

The demographic data for the same period of time comes from the Brazilian Institute of Geography and Statistics (IBGE). It estimates the canine population as $10 \%$ of the human population (WHO/WSPA, 1992).

The vector of AVL was considered to be present in all municipalities. The AVL cases were georeferenced in the field with aid of a global positioning system

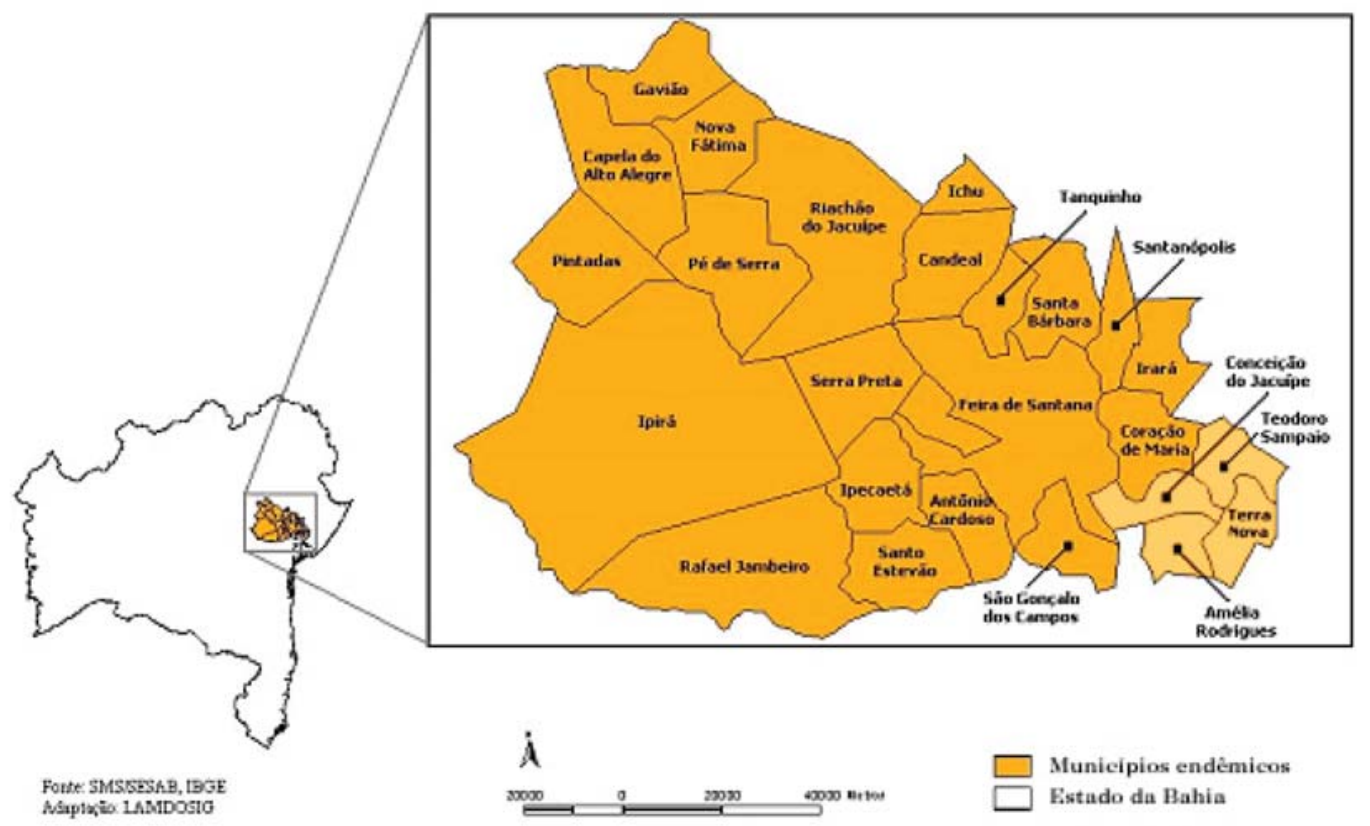

Fig. 1. The geographic region of study which includes the municipalities of the center-east region of Bahia, Brazil. 
(GPS) receiver (model ETREX, Garmin). The coordinates were measured in the System of Projection UTM, datum SAD69 (South America, 1969).

\section{Tests for the detection of agglomerates}

Agglomeration of cases can be appraised as a group event, geographically limited in concentration and size and the level of risk accounted for in a way that excludes randomness. The data in this study were analyzed with the aim of detecting aggregates of cases using a purely spatial approach (when the cases occurred in the same region or area investigated) and a spatio-temporal approach (when spatial and temporal proximity between the cases exists simultaneously) as described by Werneck and Struchiner (1997) and Lawson and Kulldorff (1999).

Initially, we used a generic-type statistics approach for testing the hypothesis of non-existent risk of agglomeration of AVL in the study area against the alternative hypothesis of the existence of some aggregation but without specifying where in the area it might exist. This was done controlling for random aggregation as described and used by Lawson and Kulldorff (1999), Assunção (2001) and Pellegrini (2002).

A number of cases were found in each study area and their numbers all followed a Poisson distribution. The number of cases expected in one determined area is equal $\theta$ times the population at risk. The constant $\theta$ mentions the per capita rate of occurrence of events in the area that under the null hypothesis possesses the same value in all and any area or sub-region of the map. In the alternative hypothesis, it can be admitted that some sub-regions of the map have a value of $\theta$ greater inside than outside of it (Beato-Filho et al., 2001).

The statistical tests of the spatial scanning results were carried out using the SaTScan ${ }^{\mathrm{TM}}$ software version 7.0, which is available free of charge at the website www.satscan.org. The approach idealized by Kulldorff and Nagarwalla (1995), was applied with the following variables: the population of the territorial unit (municipality), coordinates of the centroids of the cases found (human and canine), number of cases for each municipality, year of occurrence, and the gender of the positive human cases (co-variable). For each municipality, the center of centroid mass was calculated, denominated centroid, through the extension for the ArcView 3.x. Jenness Enterprises (2004), available at www.jennessent.com/arcview/centermass.htm.

For the analysis of the data the SaTScan ${ }^{\mathrm{TM}}$ was configured to:

(i) carry out both a purely spatial analysis and a spatio-temporal one;

(ii) use the interval of annual time;

(iii) conform to the probability distribution of Poisson (where the distribution is heterogeneous and the events are rare in relation to the population);

(iv) consider clusters with $10 \%, 30 \%$ and $50 \%$ of the population at risk; and

(v) submit each one of these to replication 999, 9999 and 99,999 times (to generate a number of random replications of the data set under the null hypothesis).

\section{Results}

On the basis of the parameters configured for analysis through the SaTScan ${ }^{\mathrm{TM}}$, the best result was obtained by the mathematical model that considered a maximum of $30 \%$ of the population at risk for leishmaniasis and a 999-time Monte Carlo simulation. This model detected agglomerates of primary and secondary risk clusters at a high statistical level of significance ( $\mathrm{P}<0.001)$. Using the $10 \%$ and $50 \%$ levels of population at risk in the model produced either an excess of secondary clusters and/or p-values without statistical significance.

During the 1994-2004 period, the estimated total population in the study area was 944,657 and the relative risk was 7.3 in 100,000. Analysis based on purely spatial scanning of this area detected two risk agglomerates which included $55 \%$ of all registered cases (Fig. 2). 


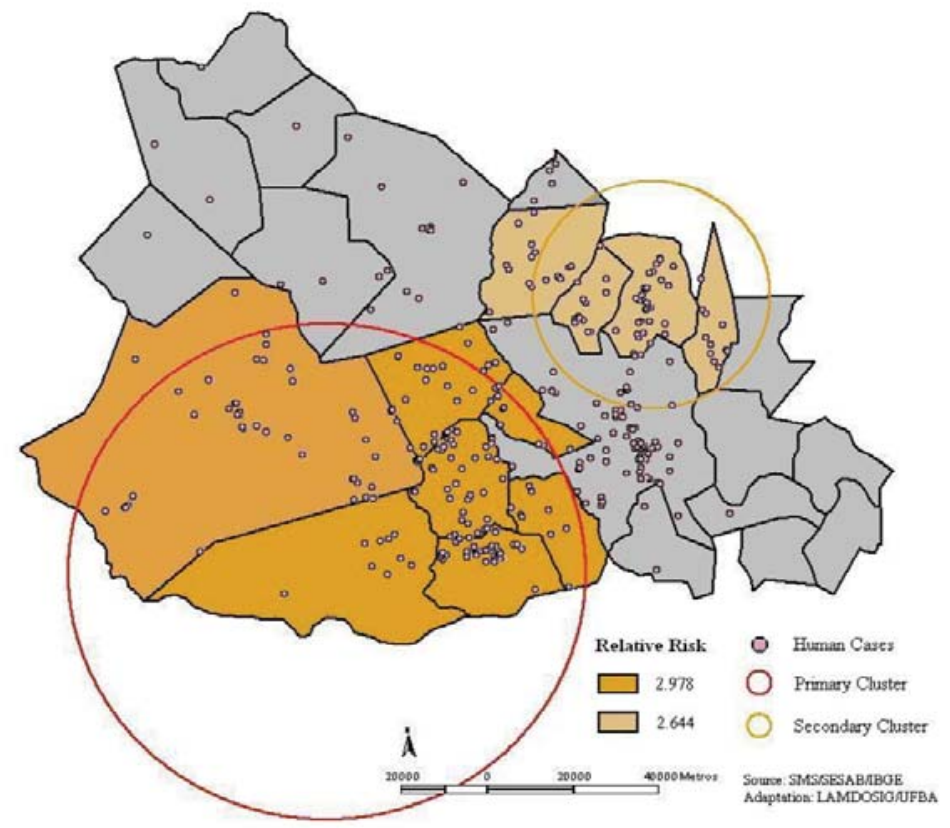

Fig. 2. Detection of human AVL clusters in the study area in Bahia (Brazil), during the period 1994-2004 through analysis based on purely spatial scanning.

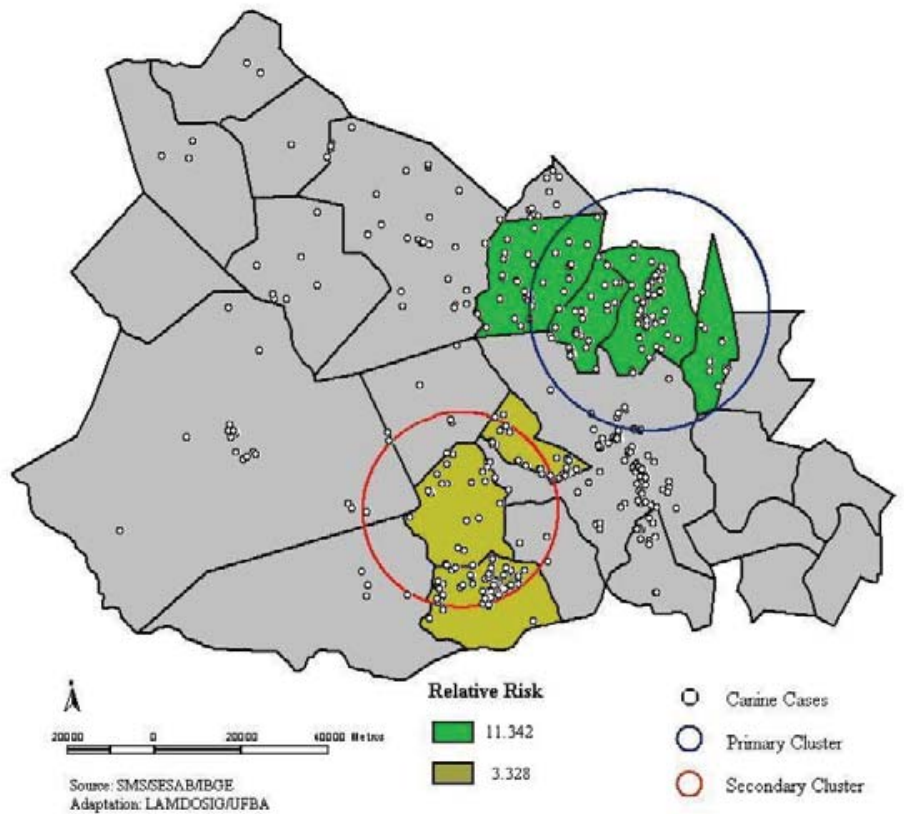

Fig. 3. Detection of canine AVL clusters in the study area in Bahia (Brazil), during the period 1994-2004 through analysis based on purely spatial scanning. 
The agglomerate with the highest probability of being true was termed the primary. It involved seven municipalities of the eastern region originating from Rafael Jambeiro, a community with 180,308 inhabitants whose gross rate was 15.8 per 100,000 inhabitants and the relative risk 2.978 (Table 1). This agglomerate included 314 human registered cases of AVL, while we should have had, under the null hypothesis, only around 145.3 cases, resulting in a cluster ratio of 2.161 .

The secondary agglomerate was composed of four municipalities issuing from Santa Bárbara with 51,096 inhabitants and a risk rate of 2.644. Although the number of cases expected for this area was 43.0, as many as 104 cases had been registered giving a cluster ratio of 2.419 (Table 1).

The purely spatial analysis for detection of risk agglomerates for canine AVL for the 1994-2004 period comprised 26 municipalities with an estimated canine population of 93,554 animals and an annual risk rate of 114.6 in 100,000 . The analysis of the canine data detected two aggregates at a highly statistically significant level ( $\mathrm{P}<0.001)$ (Fig. 3).

The primary agglomerate was constituted of four municipalities from Santa Bárbara, whose radius at the time of the study reached an estimated canine population of 4383 animals with a relative risk of 11.342. In this area, 422 seropositive animals had been registered, while 55.2 infected canines should have been expected under the null hypothesis. The rate of annual risk was calculated to 875 in 100,000 animals. The secondary agglomerate was centered over the municipality of Ipecaetá and involved three municipalities where 6378 dogs lived. The relative risk was 3.328 and the annual risk rate was calculated at 326 in 100,000 dogs. However, while 84.9 positive cases were expected, 242 were actually observed (Table 2).

Secondly, a retrospective statistical analysis of scanning over a period of time was done with the aim of detecting disease clusters in humans. The initial results were identical to the purely spatial analysis but only with reference to population, number of cases and the annual rate of risk. However, when individuals affected by the disease were taken into account, two agglomerates with strong statistical significance $(\mathrm{P}<0.001)$ were formed (Fig. 4).

The primary agglomerate was detected to have existed between 1996 and 2000 in the same municipalities covered by the purely spatial analysis. Thus, the population and covering radius coincided. In contrast to the approximately 65.3 cases of disease to be expected under the null hypothesis for the period investigated, 240 cases had been reported, i.e. a ratio between observed and expected cases of 3.674 (Table 3). The rate of annual risk was estimated at 26.9 in 100,000 inhabitants and the relative risk at 4.907 .

Table 1. Cluster distribution of human AVL cases for the 1994-2004 period in the municipalities of the study area in Bahia (Brazil) based on purely spatial analysis.

\begin{tabular}{|c|c|c|c|c|c|c|c|c|c|c|}
\hline Cluster & Municipality & P-value & $\begin{array}{l}\text { Clusters } \\
\text { observed }\end{array}$ & $\begin{array}{l}\text { Clusters } \\
\text { expected }\end{array}$ & $\begin{array}{c}\text { Ratio } \\
\text { (obs/exp) }\end{array}$ & $\begin{array}{l}\text { Relative } \\
\text { risk }\end{array}$ & $\begin{array}{c}\text { Observed } \\
\text { cases }\end{array}$ & $\begin{array}{l}\text { Expected } \\
\text { cases }\end{array}$ & $\begin{array}{c}\text { Ratio } \\
\text { (obs/exp) }\end{array}$ & $\begin{array}{c}\text { Relative } \\
\text { risk }\end{array}$ \\
\hline \multirow[t]{7}{*}{ Primary } & Rafael Jambeiro & $<0.001$ & 314 & 145.3 & 2.161 & 2.978 & 22 & 17.7 & 1.243 & 1.250 \\
\hline & Santo Estevão & $<0.001$ & 314 & 145.3 & 2.161 & 2.978 & 62 & 32.7 & 1.894 & 1.974 \\
\hline & Ipecaetá & $<0.001$ & 314 & 145.3 & 2.161 & 2.978 & 73 & 14.4 & 5.060 & 5.492 \\
\hline & Ipirá & $<0.001$ & 314 & 145.3 & 2.161 & 2.978 & 87 & 50.5 & 1.722 & 1.815 \\
\hline & Serra Preta & $<0.001$ & 314 & 145.3 & 2.161 & 2.978 & 44 & 13.8 & 3.193 & 3.328 \\
\hline & Antônio Cardoso & $<0.001$ & 314 & 145.3 & 2.161 & 2.978 & 10 & 9.2 & 1.090 & 1.091 \\
\hline & Anguera & $<0.001$ & 314 & 145.3 & 2.161 & 2.978 & 16 & 7.0 & 2.296 & 2.324 \\
\hline \multirow[t]{4}{*}{ Secondary } & Santa Bárbara & $<0.001$ & 104 & 43.0 & 2.419 & 2.644 & 51 & 21.9 & 2.326 & 2.421 \\
\hline & Tanquinho & $<0.001$ & 104 & 43.0 & 2.419 & 2.644 & 17 & 6.2 & 2.748 & 2.788 \\
\hline & Santanópolis & $<0.001$ & 104 & 43.0 & 2.419 & 2.644 & 13 & 6.9 & 1.899 & 1.915 \\
\hline & Candeal & $<0.001$ & 104 & 43.0 & 2.419 & 2.644 & 23 & 8.0 & 2.865 & 2.923 \\
\hline
\end{tabular}


Table 2. Cluster distribution of canine AVL cases for the 1994-2004 period in the municipalities of the study area in Bahia (Brazil) based on purely spatial analysis.

\begin{tabular}{llllllrrrrr}
\hline Cluster & Municipality & P-value & $\begin{array}{c}\text { Clusters } \\
\text { observed }\end{array}$ & $\begin{array}{c}\text { Clusters } \\
\text { expected }\end{array}$ & $\begin{array}{c}\text { Ratio } \\
\text { (obs/exp) }\end{array}$ & $\begin{array}{c}\text { Relative } \\
\text { risk }\end{array}$ & $\begin{array}{c}\text { Observed } \\
\text { cases }\end{array}$ & $\begin{array}{c}\text { Expected } \\
\text { cases }\end{array}$ & $\begin{array}{c}\text { Ratio } \\
\text { (obs/exp) }\end{array}$ & $\begin{array}{c}\text { Relative } \\
\text { risk }\end{array}$ \\
\hline \multirow{2}{*}{ Primary } & Santa Bárbara & $<0.001$ & 422 & 55.2 & 7.640 & 11.342 & 227 & 22.4 & 10.121 & 12.295 \\
& Tanquinho & $<0.001$ & 422 & 55.2 & 7.640 & 11.342 & 69 & 9.7 & 7.151 & 7.533 \\
& Santanópolis & $<0.001$ & 422 & 55.2 & 7.640 & 11.342 & 59 & 10.7 & 5.527 & 5.765 \\
& Candeal & $<0.001$ & 422 & 55.2 & 7.640 & 11.342 & 67 & 12.5 & 5.368 & 5.632 \\
\multirow{2}{*}{ Secondary } & Ipecaetá & $<0.001$ & 242 & 84.9 & 2.850 & 3.328 & 65 & 22.5 & 2.883 & 2.993 \\
& Anguera & $<0.001$ & 242 & 84.9 & 2.850 & 3.328 & 53 & 10.9 & 4.852 & 5.033 \\
& Santo Estevão & $<0.001$ & 242 & 84.9 & 2.850 & 3.328 & 124 & 51.4 & 2.410 & 2.576 \\
\hline
\end{tabular}

Table 3. Cluster distribution of human AVL cases in the municipalities of the study area in Bahia (Brazil) during the period 1994-2004 through analysis of retrospective spatio-temporal scanning.

\begin{tabular}{|c|c|c|c|c|c|c|c|c|c|c|}
\hline Cluster & Municipality & P-value & $\begin{array}{l}\text { Clusters } \\
\text { observed }\end{array}$ & $\begin{array}{l}\text { Clusters } \\
\text { expected }\end{array}$ & $\begin{array}{c}\text { Ratio } \\
\text { (obs/exp) }\end{array}$ & $\begin{array}{l}\text { Relative } \\
\text { risk }\end{array}$ & $\begin{array}{c}\text { Observed } \\
\text { cases }\end{array}$ & $\begin{array}{l}\text { Expected } \\
\text { cases }\end{array}$ & $\begin{array}{c}\text { Ratio } \\
\text { (obs/exp) }\end{array}$ & $\begin{array}{l}\text { Relative } \\
\text { risk }\end{array}$ \\
\hline \multirow{7}{*}{$\begin{array}{l}\text { Primary } \\
(1996-2000)\end{array}$} & Rafael Jambeiro & $<0.001$ & 240 & 65.3 & 3.674 & 4.907 & 14 & 7.8 & 1.803 & 1.818 \\
\hline & Santo Estevão & $<0.001$ & 240 & 65.3 & 3.674 & 4.907 & 58 & 14.7 & 3.945 & 4.189 \\
\hline & Ipecaetá & $<0.001$ & 240 & 65.3 & 3.674 & 4.907 & 58 & 6.5 & 8.893 & 9.545 \\
\hline & Ipirá & $<0.001$ & 240 & 65.3 & 3.674 & 4.907 & 67 & 23.1 & 2.907 & 3.092 \\
\hline & Serra Preta & $<0.001$ & 240 & 65.3 & 3.674 & 4.907 & 24 & 6.0 & 3.974 & 4.071 \\
\hline & Antônio Cardoso & $<0.001$ & 240 & 65.3 & 3.674 & 4.907 & 06 & 4.1 & 1.460 & 1.464 \\
\hline & Anguera & $<0.001$ & 240 & 65.3 & 3.674 & 4.907 & 13 & 3.2 & 4.128 & 4.183 \\
\hline \multirow{3}{*}{$\begin{array}{l}\text { Secondary } \\
(1995-1999)\end{array}$} & Santa Bárbara & $<0.001$ & 75 & 12.9 & 5.799 & 6.324 & 11 & 2.9 & 3.765 & 3.806 \\
\hline & Tanquinho & $<0.001$ & 75 & 12.9 & 5.799 & 6.324 & 43 & 6.4 & 6.696 & 7.038 \\
\hline & Candeal & $<0.001$ & 75 & 12.9 & 5.799 & 6.324 & 21 & 3.6 & 5.847 & 5.985 \\
\hline
\end{tabular}

Table 4. Cluster distribution of canine AVL cases in the municipalities of the study area in Bahia (Brazil) during the period 1994-2004 through analysis of retrospective spatio-temporal scanning.

\begin{tabular}{llllllrrrrr}
\hline Cluster & Municipality & P-value & $\begin{array}{c}\text { Clusters } \\
\text { observed }\end{array}$ & $\begin{array}{c}\text { Clusters } \\
\text { expected }\end{array}$ & $\begin{array}{c}\text { Ratio } \\
\text { (obs/exp) }\end{array}$ & $\begin{array}{c}\text { Relative } \\
\text { risk }\end{array}$ & $\begin{array}{c}\text { Observed } \\
\text { cases }\end{array}$ & $\begin{array}{c}\text { Expected } \\
\text { cases }\end{array}$ & $\begin{array}{c}\text { Ratio } \\
\text { (obs/exp) }\end{array}$ & $\begin{array}{c}\text { Relative } \\
\text { risk }\end{array}$ \\
\hline Primary & Ichu & $<0.001$ & 452 & 36.6 & 12.348 & 19.403 & 20 & 2.7 & 8.074 & 8.196 \\
$(1999-2001)$ & Candeal & $<0.001$ & 452 & 36.6 & 12.348 & 19.403 & 51 & 3.3 & 15.275 & 15.921 \\
& Tanquinho & $<0.001$ & 452 & 36.6 & 12.348 & 19.403 & 49 & 2.5 & 20.002 & 20.826 \\
& Santa Bárbara & $<0.001$ & 452 & 36.6 & 12.348 & 19.403 & 182 & 6.2 & 29.489 & 34.689 \\
& Riachão do Jacuípe & $<0.001$ & 452 & 36.6 & 12.348 & 19.403 & 37 & 10.5 & 3.541 \\
& Santanópolis & $<0.001$ & 452 & 36.6 & 12.348 & 19.403 & 48 & 2.9 & 16.851 & 17.524 \\
& Serra Preta & $<0.001$ & 452 & 36.6 & 12.348 & 19.403 & 12 & 5.8 & 2.057 & 2.068 \\
& Anguera & $<0.001$ & 452 & 36.6 & 12.348 & 19.403 & 53 & 3.0 & 17.455 & 18.230 \\
& & & & & & & & & \\
Secondary & São Gonçalo dos & $<0.001$ & 23 & 3.1 & 7.360 & 7.486 & 23 & 3.1 & 7.360 & 7.486 \\
(2001) & Campos & & & & & & & & \\
\hline
\end{tabular}




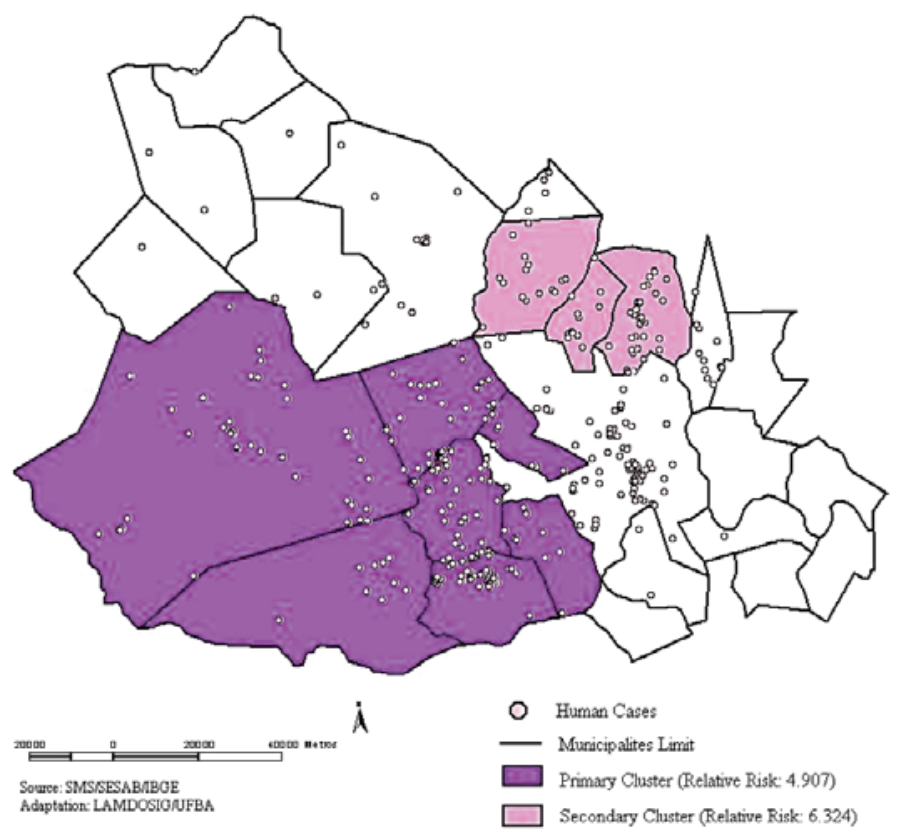

Fig. 4. Detection of human AVL clusters in the municipalities of the study area in Bahia (Brazil) during the period 1994-2004 through analysis of retrospective spatio-temporal scanning.

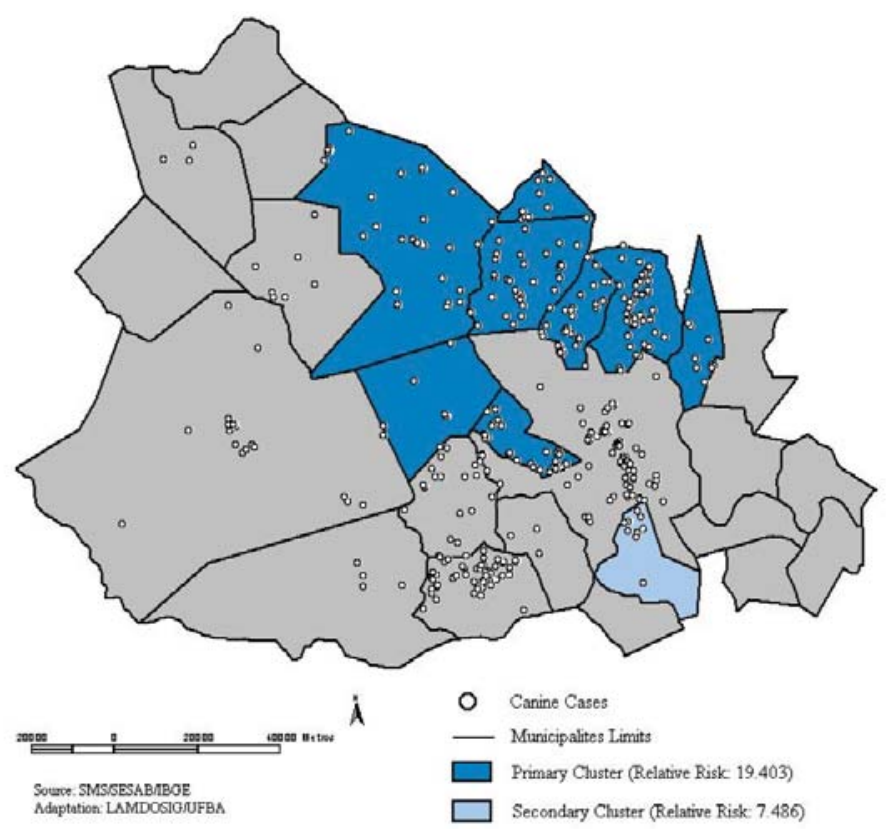

Fig. 5. Detection of canine AVL clusters in the municipalities of the study area in Bahia (Brazil) during the period 1994-2004 through analysis of retrospective spatio-temporal scanning. 
The second agglomerate was formed between the years of 1995 and 1999 and included only three municipalities (Candeal, Santa Bárbara and Tanquinho) using purely spatial analysis. Although the expected outcome for the region was 12.9 cases, 75 people with AVL were in fact observed. The annual rate was 42.4 for 100,000 individuals and the relative risk 6.324 (Table 3 ).

By the spatio-temporal analysis of the canine cases, the same general result in population terms was observed, i.e. the number of cases and rates of annual risk were detected in the two agglomerates with strong statistical significance $(\mathrm{P}<0.001)$ (Fig. 5).

The primary agglomerate was formed in the period of 1999 to 2001. The spatio-temporal approach added four more municipalities (Anguera, Ichu, Riachão do Jacuípe and Serra Preta) to the four provided by purely spatial analysis. Here, approxmately 36.6 cases were expected, while as many as 452 canines had been reported as infected. The risk was calculated to 1414 in 100,000 animals and the relative risk was 19.403 . The secondary agglomerate, found to exist in 2001, included only one municipality. Here 23 infected dogs were found, while only 3.1 were expected. The annual risk rate was 843 in 100,000 animals with a relative risk of 7.486 (Table 4).

\section{Discussion}

The method for detection of risk agglomerates, discussed by Kulldorf and Nagarwalla (1995), is based on weighing the probability of how the areas investigated really are close to the true situation. According to these authors, agglomerates may be found by applying statistics to the results of multidimensional scanning for three basic properties:

(i) the geometry of the area scanned;

(ii) the distribution of probability that generates the cases under the hypothesis of complete spatial randomness; and

(iii) the type (size and form) of the scanning window.

The purely spatial scanning model generates circular windows of variable size over the geographical area to which the model is applied. The size and localization of the windows indicate candidate areas where there is a risk for aggregation of cases. For each such a candidate area, the verisimilitude is calculated based on the observation between the expected number of cases inside and outside of the area. Of the various mathematical models, the one where $30 \%$ of the population displayed risk of illness turned out to be more significant for the study than the others. On the basis of its maximum verisimilitude, the purely spatial model generated two agglomerates constituting risk for human AVL in the region studied.

The method of detection of spatial clusters, considered by Kulldorf and Nagarwalla (1995), provides several advantages, including:

(i) clearly displays the spatial differences between various populations at risk;

(ii) prevents pre-selection contamination;

(iii) offers correct solutions for the problem of multiple comparisons; and

(iv) locates clusters on existing maps.

On the other hand, the method has a tendency to produce agglomerates which are bigger than they are in reality. This is due to a function of the search form used by SaTScan ${ }^{\mathrm{TM}}$ which produces circles rather than other geometric forms (Beato-Filho et al., 2001). This is evident in the work presented here as the circular windows (Kulldorff, 1997) integrated some sub-regions that were, in fact, not part of the real agglomerate.

The detected primary agglomerate must be considered to reflect the most likely cluster (since the value of $\mathrm{L}_{(\mathrm{z})}$ is almost as high as that of $\mathrm{L}_{(\check{z})}$ which represents the maximum likelihood) and therefore constitutes a believable risk for human AVL. The municipalities included in this agglomerate (Rafael Jambeiro, Santa Estevão, Ipecaetá, Ipirá, Serra Preta, Antonio Cardoso and Anguera), despite AVL being a disease that must be officially registered, in fact did not report $41 \%$ (314/760) of the cases observed in the study period. It is thus probable that the official number of cases comprises only those who only seek care when they become seriously 
compromised plus those who are found as a function of passive detection (Moreno et al., 2002; Hailu et al., 2005). In this particular case, the number of observed patients was double the expected and it seems credible that the situation is not much different in other areas, i.e. the real number of infected people is generally higher than the official figure. As seen in Table 1, the people living in these risk areas have almost a three (2.978) times higher possibility to acquire the disease than the inhabitants of the other municipalities composing the cluster.

According to the literature (Lutz and Neiva, 1912; Forattini, 1973; Rebêlo, 1999; Brasil, 2006), and on the basis of further studies carried out in this endemic area (unpublished data), the increased risk for humans can be explained by the climate and the phyto-geographic environment. Consequently, the semi-arid, sub-humid to dry area, characterized by caatinga growth, favors the Lutzomyia longipalpis vector and the transmission of the etiologic agent to the human host (Lutz and Neiva, 1912; Forattini, 1973; Rebêlo, 1999). Furthermore, the existence of $27 \%$ of the registered dogs in this area confirms the importance of this animal as reservoir (CamargoNeves et al., 2001; Lainson et al., 2002).

Amongst the municipalities belonging to this cluster, Ipecaetá represented the highest relative risk for AVL, i.e. five times more than the average. From observations in loco, the majority of the georeferenced addresses exhibited one or more of the typical physical and geographical risk factors, i.e. habitation in deforested areas, transition from agricultural to urban occupancy, precarious life at low socioeconomic levels, animal shelters (pigsties, hen houses, corrals) next to the residences and presence of dogs. The risk of the evidence cited is supported by the literature (Alexander et al., 2002; Moreira et al., 2003; Tavares-Neto et al. 2003; Carneiro et al., 2004; Dantas-Torres and Brandão-Filho, 2006; Moraes-Silva et al., 2006).

The data related to the secondary clusters must be analyzed with prudence once the associated p-value is conservative which means that they are considerably larger than the real ones (Beato-Filho et al.,
2001). In our study, these secondary clusters were considered to represent a lower risk despite the agglomerates being statistically significant. Indeed, a greater ratio was observed between the number of human cases found in these clusters and the expected outcome in the municipalities of Candeal and Tanquinho.

Purely spatial analysis found more than half of the canine infections reported to the health agencies. The published general rate of seropositive dogs reached $22.3 \%$. To control this domestic leishmaniasis reservoir, the Secretariat of Vigilance and Health of the Ministry of Health called in and sacrificed all the dogs in the affected areas (Brasil, $2006)$. The greatest gross positive rate $(21.7 \%)$ of the disease was detected in the primary agglomerate. According to observations in the area (data not published), the municipalities exhibit environments that favours the vector species and the transmission of the enzootia in the canine population, i.e. semi-arid, sub-humid and dry landscapes, sometimes characterized by hills and valleys as in Tanquinho and Candeal, with a predominance of transition areas with seasonal caatinga growth and small areas of cattle agriculture. This is corroborated also by other authors (Lutz and Neiva, 1912; Rêbelo, 1999; Bavia et al., 2005; Brasil, 2006).

The municipality of Santa Bárbara presented the largest number of canine cases of all the endemic municipalities and the greatest relative risk of any cluster, i.e. a dog in this vicinity was 12 times more likely to be infected than in others. The positive dogs were georeferenced and a majority of them were found to habitually roam the agricultural zone of the municipalities. As observed in loco, the residential areas and their immediate neighbourhoods were characterized by arboreta (firewood, trunks of trees, roots, rocks, garbage and other materials subject to organic decomposition) and sheds (hen houses, pigsties, corrals). This scene offers excellent conditions for the phlebotomine vector that depends on hematophagy (the female) to survive and therefore perpetuates the cycle and spreads the disease (Lutz and Neiva, 1912; Forattini, 1973; Rêbelo, 1999; 
Camargo-Neves et al., 2001; Alexander et al., 2002; Moreira et al., 2003; Moraes-Silva et al., 2006). Amongst the municipalities of the secondary agglomerate, Anguera, followed by Ipecaetá, presented the greatest risk for the canine population.

In the comparative analysis between the agglomerates of risk detected, it was observed that the municipalities of the primary agglomerate of human infections coincided with the secondary agglomerate of infected canines in only three municipalities (Anguera, Ipecaetá and Santo Estevão). While the secondary human agglomerate (Candeal, Santa Bárbara, Santanópolis and Tanquinho) also constituted the most likely one with reference to the dogs, as it had a greater dog/human ratio of infection as well as a greater canine density (22.7) which was particularly evident in Santa Bárbara. Taking into account that the mumber of dogs in an endemic area influences the number of human infections and that canine enzootia precedes human cases (Bevilacqua et al., 2001; Carneiro et al., 2004; Bavia et al., 2005), we infer that the secondary canine agglomerates can constitute a cluster of primary risk for humans.

The spatio-temporal statistics suggested by Kulldorff (1997) is analogous to purely spatial scanning and defined for a cylindrical window with a circular geographic base and corresponding weight to time. The base is centered in the some centroids of the study area with a variable radius of constant form. The retrospective spatio-temporal analysis of the human data considered all the municipalities subjected to purely spatial analysis with the exception of Santanópolis. In total, there were $53.3 \%$ registered cases and $22 \%$ deaths. Despite a whole decade was studied, only two agglomerates of human AVL were detected. However, even if the software used is very sensitive and it was expected that agglomerates would be found for every year studied, the magnitude of the outbreaks in 1996 and 2001 might have masked other possible agglomerates. This same trend has been observed in other epidemiological studies as reported, for example, by Pellegrini (2000) who analyzed spatial-secular lep- tospirosis in the municipality of Rio de Janeiro.

The primary agglomerate was detected in the period of the outbreak (1996-2000) and presented approximately $31 \%$ of the cases notified by SMS for the whole area. In the municipalities of Ipecaetá, that showed the greatest risk of illness (9.5), it was observed that the epidemic was initiated in the same year (1996). This initiated control activities and surveillance recorded an oscillating prevalence in the following years and increasing again in 2001.

The secondary cluster was composed of the municipalities of Candeal, Tanquinho and Santa Bárbara in the 1995-1999 period presenting higher relative risk in comparison with the primary cluster. This situation probably occurred as a function of a lower number of involved municipalities, which reduced the radius of the cluster and thus raised the risk. This time of the discovery of the agglomerate also coincided with the epidemic years in Candeal, Tanquinho and Santa Bárbara.

In the spatio-temporal analysis, it was observed that clusters of risk for canine infection had been detected in the period of 1999 to 2001 . It is possible, even probable, that the years when the epidemic took place made it difficult to detect agglomerates at later times, as supported by the analysis of the human data. In the primary agglomerate that involved eight municipalities, the greatest number of registered cases occurred in 1999 (22\%) and 2001 (9\%). Santa Bárbara had a 35 times greater risk of canine enzootia and thereby registered the greatest relative risk of all the municipalities in the study.

The secondary agglomerate was detected only in 2001. This was in the municipality of Sao de Gonçalo dos Campos where the greatest magnitude of recorded enzootia $(74 \%)$ occurred. This municipality might be considered as an area of significant risk for endemic disease: for each human infected with AVL around eight infected dogs were found. This high ratio is extreme and, in addition, since canine enzootia precedes the human cases (Bevilacqua et al., 2001; Carneiro et al., 2004; Gurgel et al., 2005) is quite possible that it will increase further in the future as has indeed been 
reported in other areas (Brasil, 2004; Genaro, 1995).

\section{Conclusions}

Spatial scanning analysis using SaTScan ${ }^{\mathrm{TM}}$ permits the identification of AVL clusters and the classification of risk for humans and canines which act as the reservoir for the human infection.

Although São Gonçalo dos Campos was not in the primary cluster of humans and dogs, we can infer that this municipality carries a potential risk for unaffected municipalities since its extreme rate of human to dog infection ratio $(1: 8)$ can easily expand the disease well beyond territorial borders and administrative divisions.

Other potential co-variables, for example socioeconomic and environmental issues, could add useful perspectives to the subject of study and should be contemplated for future risk analyses using SaTScan ${ }^{\mathrm{TM}}$ and its associated mathematical models.

\section{Acknowledgements}

We thank the Foundation of Research Support for State Bahia (FAPESB) for financial support; Secretary of Municipalities Health Office (SMS) and Secretary of Health for State of Bahia (SESAB) for accessibility and viability of work development; Laboratory of Geoprocessing of the State University of Feira de Santana (UEFS) for processing of the images of satellite; and the Laboratory of Diseases Monitoring by Geographical Information System (LAMDOSIG/UFBA) for modeling of the database and assembly of the GIS.

\section{References}

Alexander B, De Carvalho RL, McCallum H, Pereira MH, 2002. Role of the domestic chicken (Gallus gallus) in the epidemiology of urban visceral leishmaniasis in Brazil. Emerg Infect Dis 8, 1480-1485.

Assunção RM, 2001. Estatística Espacial com Aplicações em Epidemiologia, Economia e Sociologia. $7^{\mathrm{a}}$ Escola de
Modelos de Regressão, São Carlos.

Bailey TC, Gatrell AC, 1995. Interactive spatial data analysis. Essex, Longman Scientific and Technical.

Bavia ME, Carneiro DDMT, Gurgel HC, Madureira Filho C, Barbosa MGR, 2005. Remote sensing and geographic information systems and risk of American visceral leishmaniasis in Bahia, Brazil. Parassitologia 47, 165-169.

Beato-Filho C, Assunção RM, Silva BFA, Marinho FC, Reis IA, Almeida MCM, 2001. Conglomerados de homicídios e o trafico de drogas em Belo Horizonte, Minas Gerais, Brasil, de 1995 a 1999. Cad Saúde Pub 17, 1163-1171.

Bevilacqua PD, Paixão HH, Modena CM, Castro MCPS, 2001. Urbanização da leishmaniose visceral em Belo Horizonte. Arquivo Brasileiro de Medicina Veterinária e Zootecnia 53, 1-8.

Brasil, 2004. Manual de vigilância e controle da leishmaniose visceral. Brasília, DF. Fundação Nacional de Saúde, Departamento de Vigilância Epidemiológica, pp. 120.

Brasil, 2006. Manual de vigilância e controle da leishmaniose visceral / Ministério da Saúde, Secretaria de Vigilância em Saúde, Departamento de Vigilância Epidemiológica Brasília: Editora do Ministério da Saúde, pp. 120.

Câmara G, Monteiro AM, Fuks SD, Carvalho MS, 2002. Análise espacial e geoprocessamento. São José dos Campos, SP, INPE, pp. 26.

Camargo-Neves VLF, Katz G, Rodas LAC, Poletto DW, Lage LC, Spínola RMF, Cruz OG, 2001. Utilização de ferramentas de análise espacial na vigilância epidemiológica de leishmaniose visceral americana - Araçatuba, São Paulo, Brasil, 1998-1999. Cad Saúde Púb 17, 1263-1267.

Carneiro DDMT, Bavia ME, Rocha W, Lobao J, Madureira Filho C, Oliveira JB, Silva CE, Barbosa MG, Rios RB, 2004. Identificação de áreas de risco para a leishmaniose visceral americana, através de estudos epidemiológicos e sensoriamento remoto orbital, em Feira de Santana, Bahia, Brasil (2000-2002). Rev Bai Saú Púb 28, 19-32.

Costa MA, Schrerrer LR, Assunção RM, 2006. Detecção de conglomerados espaciais com geometria arbitrária. Informática Púb 8, 17-29.

Dantas-Torres F, Brandão-Filho SP, 2006. Expansão geográfica da leishmaniose visceral no Estado de Pernambuco. Rev Soc Brasil Med Trop 39, 352-356.

Forattini OPF, 1973. Psychodidae. In: Entomologia médica. São Paulo, Ed. Universidade de São Paulo (Brasil) 4, 213-569. 
Franke CR, Staubach C, Ziller M, Schluter H, 2002a. Trends in the temporal and spatial distribution of visceral and cutaneous leishmaniasis in the state of Bahia, Brazil, from 1985 to 1999. Trans R Soc Trop Med Hyg 96, 236-241.

Franke CR, Ziller M, Staubach C, Latif M, 2002b. Impact of the El Niño/Southern Oscillation on visceral leishmaniasis, Brazil. Emerg Infect Dis 8, 914-917.

Genaro O, 1995. Leishmaniose visceral americana. In: Neves DP, Parasitologia Humana 9, (ed São Paulo, Atheneu), 64-81.

Gontijo CMF, Melo MN, 2004. Leishmaniose visceral no Brasil: quadro atual, desafios e perspectivas. Rev Brasil Epidemiol 7, 338-349.

Gurgel HC, Bavia ME, Carneiro DDMT, Silva CEP, Maduera-Filho C, Rios RB, Barbosa MGRA, 2005. Contribuição do NDVI para o estudo da leishmaniose visceral americana. In: Simpósio Brasileiro de Sensoriamento Remoto 12, 2673-2680.

Hailu A, Musa AM, Royce C, Wasunna M, 2005. Visceral leishmaniasis: new health tools are needed. PLoS Med 2, 590-591.

Hills M, Alexander F, 1989. Statistical methods used in assessing the risk of disease near a source of possible environmental pollution: a review. J R Stat Soc Ser A 152, 307-325.

IBGE (Instituto Brasileiro de Geografia e Estatistica), Rio de Janeiro, Brazil, 2000.

Instituto Nacional de Meteorologia (INMET), Brazil, 2005.

Jennes J, 2004. Center of Mass (center_of_mass.avx) extension for ArcView 3.x. Jenness Enterprises. Available at: http://www.jennessent.com/arcview/centermass.htm

Kawa H, Sabroza PC, 2002. Espacialização da leishmaniose tegumentar na cidade do Rio de Janeiro. Cad Saúde Púb 18, 853-865.

Kulldorff M, 1997. A spatial scan statistic. Commun Stat Theory Methods 26, 1481-1496.

Kulldorff M, Nagarwalla N, 1995. Spatial disease clusters: detection and inference. Stat Med 14, 799-810.

Lainson R, Ishikawa EAY, Silveira FT, 2002. American visceral leishmaniasis: wild animal hosts. Trans $\mathrm{R}$ Soc Trop Med Hyg 96, 630-631.

Lawson AB, Kulldorf M, 1999. A review of cluster detection methods. In: Disease Mapping and Risk Assessment for Public Health (Lawson AB, Biggeri A, Böhning D, Lesaffre E, Viel JF, Bertollini E eds), Chichester, John Wiley and
Sons, 99-110.

Lutz A, Neiva A, 1912. Contribuição para o conhecimento do gênero Phlebotomus existentes no Brasil. Mem Inst Oswaldo Cruz 4, 84-95.

Marshall RJ, 1991. A review of methods for the statistical analysis of spatial patterns of disease. J R Stat Soc Ser A 154, 421-441.

Miranda C, Marques CA, Massa JL, 1998. Sensoriamento remoto orbital como recurso para análise da ocorrência da Leishmaniose Tegumentar Americana em localidade urbana da região sudeste do Brasil. Rev Saúde Púb 32, 455-463.

Moraes-Silva E, Antunes FR, Rodrigues MS, Julião FS, DiasLima AG, Lemos-De-Sousa V, Alcantara AC, Reis EAG, Nakatani M, Badarò R, Reis MG, Pontes-De-Carvalho L, Franke CR, 2006. Domestic swine in a visceral leishmaniasis endemic area produce antibodies against multiple Leishmania infantum antigens but apparently resist to L. infantum infection. Acta Trop 98, 176-182.

Morais-Neto OL, Barros MBA, Martelli CMT, Silva SA, Cavenaghi SM, Siqueira JB, 2001. Diferenças no padrão de ocorrência da mortalidade neonatal e pós-neonatal no Município de Goiânia, Brasil, 1992-1996: análise espacial para identificação das áreas de risco. Cad Saúde Púb 17, 1241-1250.

Moreira Jr ED, Souza VMM, Sreenivasan M, Lopes NL, Barreto RB, Carvalho LP, 2003. Peridomestic risk factors for canine leishmaniasis in urban dwellings: new findings from a prospective study in brazil. Am J Trop Med Hyg 69, 393-397.

Moreno E, Melo MN, Antunes CMF, Lambertucci JR, Serufo JC, Andrade-Ribeiro AS, Carneiro M, 2002. Epidemiologia da Leishmaniose Visceral Humana assintomática em área urbana, Sabará, Minas Gerais, 1998-1999. Informe Epidemiológico do SUS 11, 37-39.

Oliveira SS, Araùjo TM, 2003. Avaliação das Ações de Controle da Leishmaniose Visceral (calazar) em uma Área Endêmica do Estado da Bahia, Brasil (1995-1999). Cad Saúde Púb 19, 1681-1690.

Pellegrini DCP, 2002. Análise espaço-temporal da leptospirose no município do Rio de Janeiro (1995-1999). Dissertação de Mestrado, Escola Nacional de Saúde Pública, Fiocruz, 49.

Rêbelo JMM, 1999. Flebotómos vetores das Leishmanioses. In: Manual para técnicos e profissionais da área de saúde. 
São Luís, Universidade Federal do Maranhão.

Tavares ACQ, 2006. Distribuição espaço-temporal do crime contra a vida em Salvador entre 2000 e 2004. Conclusão de Curso (Especialização em Modelagem em Ciências da Terra e do Ambiente) - Universidade Estadual de Feira de Santana, Feira de Santana, pp. 65.

Tavares-Neto J, Barral A, Queiroz-Andrade M, Oliveira S, 2003. Caracterização sócio-demográfica da população do Povoado de Cavunge - Bahia. Revista Baiana de Saúde Pública, Salvador (Bahia, Brazil) 27, 60-75.

SEI (Superintendência de Estudos Econômicos e Sociais da Bahia), 1997. Available at: <http://www.sei.ba.gov.br>

SEI (Superintendência de Estudos Econômicos e Sociais da
Bahia), 2000. Available at: <http://www.sei.ba.gov.br> SESAB (Secretaria de Saúde do Estado da Bahia), 2005. Relatório. Salvador: Diretoria de Vigilância Epidemiológica, Superintendência de Vigilância e Proteção da Saúde, SESAB. Werneck GL, Struchiner CJ, 1997. Estudos de agregados de doença no espaço-tempo: conceitos, técnicas e desafios. Cad Saúde Púb 13, 127-131.

WHO (World Health Organization), 2002. The world health report 2002: reducing risks, promoting healthy life. Geneva, Switzerland.

WHO (World Health Organization)/WSPA (World Society for the Protection of Animals), 1992. Guidelines for the dog population management, Geneva, Switzerland. 